The Geneva Papers on Risk and Insurance, 21 (No. 81, October 1996), 524-533

\title{
New Trends in Gradual Retirement in Germany*
}

\author{
by Gerhard Naegele**
}

Until recently, there was a social consensus in Germany concerning early retirement which had lasted for almost two decades. As well as most of those directly concerned, this consensus included, for different reasons, nearly all the important social groups, including the trade unions: early retirement was not only «tacitly» accepted, but in many cases also actively promoted and even financially «sweetened». One of the main reasons why this «grand early retirement coalition» lasted for more than twenty years was the situation on the labour market, because early retirement was seen by everybody as an instrument for creating new jobs or securing existing ones. Although the future situation on the labour market is expected to continue to be poor, even in the medium term, this consensus is now about to be abandoned.

Since February 1996, there has been a general «pensions compromise» in Germany which basically means: a stop to early retirement and the substitution of part-time work for older employees instead of early retirement. The compromise has the following main elements:

- From 1997 onwards, the age limit for early retirement, which is currently 60, will be raised in annual steps to 61 (end of 1997), 62 (end of 1998) and 63 (end of 1999). While there will still be the possibility of retiring up to three years earlier, though from a higher normal retirement age (63 in 1999) and with pension reductions of (an actuarially calculated) 3.6 percent per year of early retirement, for retirement three years ahead of the normal age, this will mean a permanent pension loss of almost $11 \%$.

*Paper presented at the International Seminar The Elder in the year 2000 Turin, April 15th and 16th, 1996.

** Institute for Gerontology, Dortmund University, Germany. 
These pension losses can be reduced by voluntary supplementary payments into the statutory pensions insurance scheme up to the age of 65 . Severance payments, redundancy plan resources, etc., otherwise paid for securing the financial livelihood of people taking early retirement, can and will be used for this purpose.

- With immediate effect, it will be possible for people on reaching the age of 55 to change to part-time work - provided, of course, that corresponding jobs are available, as there is no statutory requirement that such jobs be provided. By way of initial assessment, experts see precisely this absence of a requirement on the part of firms to provide parttime jobs as the shortcoming of the new scheme.

To give employees a material incentive, it is planned to top up the reduction in their pensions due to part-time working out of unemployment insurance funds for a limited period of five years (from 1996 to 2001). The top-up payment is such that for 50 percent working time, employees will receive 70 percent of their last net full-time pay. This top-up amount of 20 percent is exempt from taxation and social security contributions, and the unemployment insurance fund will also reimburse the pension contributions of older employees working part-time, on the basis of 90 percent of the full-time gross pay. The preconditions for this assistance from unemployment insurance resources are:

- that the working hours of older employees be reduced to half of full-time employment (on average: 18 hours per week);

- that the half-jobs becoming available are refilled by an unemployed person or that a trainee is kept on by the firm on completion of his or her period of training.

In the public discussion in Germany on the need for putting a stop to early retirement in future, two arguments dominate. The first is the enormous financial burden on social security insurance schemes, which have hitherto borne most of the cost of early retirement. The second is the demographic development and its consequences for the labour market. Thus, all available demographic forecasts, including Germany, predict both a decline in the overall number of employed people and at the same time an increase in the number of employed in the middle to higher age groups. In general, the period from 2010 to 2015 is seen as crucial in this respect. To close the manpower gap which is expected to occur after $2010 / 15$, extending the duration of total working life is seen as one labour-market option, especially as employee potential will then be made up of an increasing number of older workers. So - the argument goes - as older employees, given the demographic trend, will be increasingly needed in firms, public offices and on the labour market from 2010/15, an end must be made to early retirement as soon as possible.

However, the current proposal to stop early retirement comes at a bad time. Thus, not only in Germany, early retirement is seen as an important instrument of labour market policy for combating unemployment. At present, there are some 4 million people officially registered in Germany as unemployed, including, and to an increasing degree, older longterm jobless people. Stopping early retirement now would therefore not only increase unemployment overall but would also have negative social effects on many unemployed people or on young and older employees threatened by unemployment. It must be remembered in this context that labour-market forecasts assume a high base level of unem- 
ployment in Germany right up to the year 2010 and that only then will demographic easing on the labour-market start to have an effect.

The other side of the picture is, however, that - as already mentioned - there is a medium to longer-term demographically-based need to extend overall working life, at least from the year 2010/15 onwards. But this cannot be brought about in the year 2015 simply «by pressing of a button». Rather, a change in the decades-long practice of early retirement will require a protracted preparatory phase. It is reckoned that businesses alone will need 10 years to bring about a strategic change in their personnel policy, away from one centred on youth to one centred on older people. And in view of the fact that the trend towards early retirement in Germany has developed historically over more than 20 years and is now so widespread, it is generally doubted whether it will be possible to overcome it at all. Both these things therefore seem conceivable only in a longer-term perspective, if at all.

In my opinion, this longer-term perspective offers the only chance, if any, of returning in future to an adequate increase in employment among older people which will, if the demographic forecasts are correct, be necessary from 2010/15 on. Until then, if only for labour market reasons, there will be a need to retain early retirement on acceptable terms. For the period after 2010/15, however, it could become the strategic goal of labour market policy to have a larger number of older people in employment. This will, notwithstanding, require a correspondingly lengthy run-up phase if a fundamental change of attitude or of practice is to be brought about both in businesses and public offices and in older employees.

To produce this change of attitude among the older employees themselves, it will, in my view be necessary first and foremost to create or improve the objective conditions that make work in the middle and more advanced years possible on a voluntary basis. Part-time work for older employees - provided it is properly structured - could have a place in such a concept.

In addition to this, we have to be aware of fundamental changes of attitude in today's older workers. The well-known and widespread wish to retire earlier encountered in many workers all over Western Europe reflects, among other things, primarily a change in perception of working conditions, particularly during the last stages of working life. Unfavourable working conditions are, however, fundamentally shapeable and therefore changeable. The idea is that if adequate working conditions and workplace surroundings existed throughout working life and not only during the last years, the wish to stay longer in working life would be restored. One additional factor of influence can be seen in cohort effects, i.e. future generations of older workers will have higher occupational qualifications, more experience of technological change, etc. and therefore might wish to stay longer in working life because of stronger identification and higher satisfaction with their jobs.

One first conclusion is: in a mid- and long-term perspective, there can be an identity of interests within all groups, labour market politicians, employers and workers, to stay longer in working life. But the task of creating appropriate preconditions must begin right away. 
These reflections lead to some brief recommendations. First, we do not need specific working conditions explicitly for older workers, i.e. we do not need age-adequate working places, but we do need working places which allow workers to stay and grow old at work without becoming completely exhausted physically and mentally. This approach, in my view, seems to reflect a fundamental change in our assessment of the situation of older workers. To focus on working conditions during the whole life span is also necessary, given the important results of research on age-typical risk factors in working life: the most typical risks in working life by which older workers are particularly affected are: restrictions in health status on the one hand and loss of vocational qualifications on the other. Although as a rule these risks do not become evident before the later stages of working life are reached, they nevertheless have long «careers», i.e. they are «produced» in earlier stages. Therefore, it is necessary to act upon their origins and not merely upon their manifestation.

Thus, in order to promote employment of the older worker of tomorrow, it is absolutely necessary to take steps now, and in so doing to focus on today's 30 to 45 year-old workers because they will be the older workers of tomorrow. The aim must be to introduce measures now which allow the younger and middle-aged of today to stay longer in working life tomorrow. This is not only a question of individual willingness but chiefly of capability and its preconditions. In this context, key roles must be assigned to companies as well as to employers and to trade unions and work councils.

The necessary move towards more preventive company personnel policies should focus on different levels. In this connection, the following tasks can be regarded as important:

(a) To intensify all efforts towards the protection of health, including measures to humanize labour conditions: this also includes wage policy, which is by no means oriented towards achieving a long working career. Further, one important aim is also to protect long-term health status by reducing physical and mental work loads preventively and at the same time - by dropping the financial incentives which are usually paid to workers to tolerate these loads. In Germany, especially on the part of the trade union which represents the workers in the iron and steel industry, there are attempts to change wage policies accordingly.

(b) To promote measures which help harmonize with working conditions the changing performance that accompanies the ageing process: This harmonization refers to the decreasing capacity to cope with work demands and work stress.

In this context, special attention has to be given to ergonomics, to the design of the workplace, workrooms, working materials, working time, working environments, work organization, and also to the style of leadership and the behaviour of superiors. One of the most important preconditions for such measures is long-term and at the same time ageoriented personnel planning. This is lacking in almost all Western European companies.

(c) To enforce in-company and out-company measures for the promotion and maintenance of vocational performance: training should be organized and offered in the form of life-long learning and should be harmonized with special working time arrangements for the groups concerned. In doing this, it should also be remembered that the 
labour force of tomorrow will be different - a lot more heterogeneous than that of today (fewer young and more older workers, more women and more migrants) and that therefore differentiation in training courses and methods is needed. That the state must intervene here and provide appropriate incentives is in my opinion beyond question, because at present there exists absolutely no encouragement to firms to provide such facilities.

In the current labour-market and pension-policy discussion, part-time work for older employees is now regarded as an alternative to early retirement. Officially, part-time work for older workers is seen as an instrument for encouraging more older workers to stay in working life. This was precisely the main purpose of the German Partial Pension Act, introduced in 1992. It was the Swedish model of partial retirement that helped the German model into being. But in contradistinction to Sweden, hardly anybody has made use of it: only 2,000 persons out of 1.2 million workers with entitlement were registered. Also, earlier experience with company schemes or corresponding wage tariff agreements produced similarly disappointing results.

The extremely low use made of it in the past, however, does not invalidate the model itself. Rather, it reflects above all deficiencies in timing and concrete details and resistance in taking advantage of it on the part of employees and employers. Therefore, it is worth looking for the reasons for the complete failure of partial retirement schemes in order to weigh up the chances of the new German initiative of February 1996 and - besides this - to look for adequate measures to promote partial retirement and part-time work for older workers in the future.

Now let us look at the reasons for the total failure of gradual retirement schemes in Germany to date:

(1) The main reason for the failure of the Partial Pension Act of 1992 is that it did not reflect the labour market conditions properly. The implementation of gradual retirement cannot be seen as separate from the general situation of older workers on the labour market, and is, moreover, embedded in the practice of companies and unions towards older workers. Against the background of constant unfavourable employment prospects for most older workers and continuing early retirement forced by companies, a concept which aims at promoting work for older workers has no realistic chance of being successful. The demands of the labour market or lack of qualifications is one of the most important preconditions for the willingness of companies to retain or employ older workers. Successful implementation of gradual retirement depends on this.

(2) The possibility, available from 1992, of taking a partial pension did not apply until people reached the respective age limits, i.e. at the earliest at 60 and in most cases not until 63. For most of the potential beneficiaries, this possibility came much too late. It is to be expected that now that 55 has been set as the qualifying age, there will be much greater willingness to take advantage of this opportunity.

(3) Many potential beneficiaries rejected the offer because of financial losses in state pensions and in some cases also in company pensions. It remains an open question whether the financial compensation which has now been decided (see above) will be suffi- 
cient to overcome this resistance on the part of the employees. However, this first presupposes that corresponding supplementary company and/or wage tariff compensation payments are agreed. The linking of subsidies from unemployment insurance schemes to the hiring of an unemployed person or the continued employment of a young person on completion of his or her training also assumes that firms have a fundamental interest in taking on personnel, and this is unlikely in the present job market situation.

(4) In many firms and with many people in senior positions, besides general ignorance about the existence of the facility, especially the organizational and financial consequences of introduction on a broad front were seen as the main obstacles to implementation. Counterarguments refer mainly to costs as well as to practical problems. For example, increased costs are anticipated because of additional financial needs which are generally linked to the introduction of partial and flexible working time arrangements. Practical problems regarding the implementation of gradual retirement schemes are feared especially by middle management and to a lesser extent by top managers and employers' representatives. Among the problems mentioned by representatives of companies, the following can be cited:

- technical and organizational difficulties in dividing workplaces (for example, with shift systems),

- problems in finding the right partner for sharing work places, and

- the time-consuming need for coordination.

However, the acceptance of companies varies strongly with other general set-ups. Important factors are the size and the financial potential of a company as well as existing general experience with flexible working-time arrangements (for example, in companies where a high percentage of women are employed). Hardly any acceptance is found in companies which aim at a rejuvenation of the workforce.

What we also learned from our own case studies is that the concept of gradual retirement should not be restricted to classical schemes of part-time work. For example, companies see more potential for accumulating working hour reductions in the form of days or weeks off.

For the future, it is to be expected that there will at least be better publicity as more groups of society are involved in the new "pensions compromise». This will, however, not make implementation within companies easier in future.

(5) There was fear on the part of many potential beneficiaries that they would be required to change jobs and/or accept a loss of qualifications. Whether this will change in future cannot currently be assessed as nothing is known about guarantees of continuation in or return to existing jobs. But these would be central preconditions for overcoming employee resistance.

(6) A general problem of all part-time working for older employees is its isolated position at the end of the working career which - even if only because of a lack of previous experience with flexible working time models in earlier periods of life - will inevitably produce scepticism or sometimes rejection on the part of potential beneficiaries. For it 
is hardly to be expected that the sudden and unprecedented flexibilization of working hours at the end of people's working career should find acceptance and be taken advantage of, if no opportunity for anything of this kind ever existed before during an entire working life.

(7) A related fundamental weakness of all part-time work schemes for older employees has not been overcome either: namely the problem of in-company identification and «special case» classification which frequently means promotion by special arrangements for particular groups. Experience has shown that precisely the fear of stigmatization prevents many people from making use of such schemes. But as such «conspicuous features» are always connected with special working hour arrangements for specific target or age groups, this problem can presumably only be reduced by the possibility of working time flexibilization throughout the working career.

(8) Another important reason for low acceptance was the part-time working practice hitherto prevalent in Germany. Part-time work is traditionally the domain of women and predominantly involves unqualified jobs. Moreover, the work stresses in conventional part-time jobs are higher. Extending part-time work to men, and then only at the end of their working careers, is currently barely conceivable. In view of this, only the regular provision of a sufficient number of part-time jobs of a quality comparable to that of full-time jobs will be of help here in the medium to longer term. But in order to achieve this, clearer incentives which go beyond part-time working for older employees will be needed, and these are (currently) not in sight.

(9) Of absolutely crucial importance, however, for the success of the new part-time work scheme for older employees will be how the provision of corresponding part-time jobs organized in future. In the past - not excepting the partial pension arrangements of 1992 - this was left wholly to free development on the labour market, i.e. depended on company willingness. Besides the general labour market situation, precisely this absence of compulsion for businesses was seen by experts as the decisive reason for the failure of the partial pension and part-time working schemes for older employees. As nothing is yet known of appropriate new incentives - apart from the subsidies paid from unemployment insurance resources in the case of reemployment/hiring of new personnel - there is for the time being great scepticism as to whether the new scheme will be more successful. But given the present situation on the labour market, why should it be? As long as there is no clearly defined employee entitlement, scepticism continues to prevail.

Many businesses find it difficult to accept a new work-time policy of this kind, and therefore national or wage-tariff incentives are necessary. In addition, the still dominant (male) working-time interests are likely to keep resistance alive for some years to come. So to this extent, part-time working for older employees - wholly irrespective of the scheme which has now been decided upon and which has very considerable implementation problems of its own - will for the foreseeable future be no real alternative to early retirement on full pension. This should not be considered as a vote in favour of a general strategy of further reducing overall working life, as that would be irresponsible if only because of the demographic forecasts. But what is certain is that given both urgent labour market problems and imminent demographic challenges, strategies which are restricted 
solely to the institutional aspect of pensions insurance [and, at that, with savings primarily in mind] will not be sufficient. What is needed in future are framework conditions for the wholesale reorganization of employment for older people altogether, of which part-time working - and even then only as an integral part of an overall concept for the reorganization of overall working life - can only be a small and moreover wholly inadequate module. This is not to say that agreement on this issue is unwelcome, but merely that agreement is but the first step in a process toward ensuring a real future for part-time work.

\section{REFERENCES}

BÄCKER, G. (1995): Zukunft mit alternden Belegschaften. In: forum demographie und politik, 7. S, 35-44.

BÄCKER, G., NAEGELE, G. (1992a): Alternde Gesellschaft und Erwerbsarbeit im Alter. Anforderungen an Beschäftigungssicherung und -förderung. In: Klose, H.-U. (Hrsg.): Altern der Gesellschaft. Antworten auf den demographischen Wandel. Köln: Bund-Verlag. S. 95-120.

BÄCKER, G., NAEGELE, G. (1992b): Geht die Entberuflichung des Alters zu Ende? - Perspektiven einer Neuorganisation der Alterserwerbsarbeit. In: Naegele, G., Tews, H.P. (Hrsg.): Lebenslagen im Strukturwandel des Alters. Alternde Gesellschaft - Folgen für die Politik. Opladen: Westdeutscher-Verlag. S. 135-157.

BÄCKER, G., NAEGELE, G. (1992c): «Heifl geliebt - aber dennoch verschmäht» - Der gleitende Ruhestand in Theorie und Praxis - Ergebnisse eines Forschungsprojektes. In: Zeitschrift für Sozialreform, 9. S. 504-519.

BÄCKER, G., NAEGELE, G. (1993): Alternde Gesellschaft und Erwerbstätigkeit. Modelle zum bergang vom Erwerbsleben in den Ruhestand. Köln: Bund-Verlag.

BÄCKER, G., NAEGELE, G. (1995): Ältere Arbeitnehmer zwischen Langzeitarbeitslosigkeit und Frühverrentung. In: WSI-Mitteilungen, 12. S. $777-784$.

BANGEL, B. (1993): Geographie der Altersgrenzen. Frühverrentung im regionalen Strukturwandel. Berlin: Edition Sigma.

BARKHOLT et al. (1995): BARKHOLT, C., FRERICHS, F., NAEGELE, G.: Altersübergreifende Qualifizierung - eine Strategie zur betrieblichen Integration älterer Arbeitnehmer. In: Mitteilungen aus der Arbeitsmarkt- und Berufsforschung, 3. S. 425-438.

BAUER et al. (1994): BAUER, F., GROß, H., SCHILlING, G.: Arbeitszeit '93. Arbeitszeiten, Arbeitszeitwünsche, Zeitbewirtschaftung und Arbeitszeitgestaltungschancen von abhängig Beschäftigten. Forschungsbericht des ISO-Institutes. Köln.

BEHREND, C. (Hrsg.): Frühinvalidität - ein «Ventil» des Arbeitsmarkts? Beiträge des Deutschen Zentrums für Altersfragen zur Gerontologie und Altenarbeit, 90. Berlin: DZA-Eigenverlag.

BOGAI, D. et al. (1994): Binnenstruktur der Langzeitarbeitslosigkeit älterer Männer und Frauen. In MittAB, 2. S. 73-93.

Bundesanstalt für Arbeit (Hrsg.) (1995): Arbeitsmarkt 1994. In: Amtliche Nachrichten der Bundesanstalt für Arbeit, Sondernummer. Nürnberg. 
Deutscher Bundestag (Hrsg.) (1994): Zwischenbericht der ENQUETE-KOMMISSION Demographischer Wandel. Herausforderungen unserer älterwerdenden Gesellschaft an den einzelnen und die Politik. Zur Sache, Themen parlamentarischer Beratung, 4. Bonn: BT-Druckerei.

Deutscher Bundestag (1995): Rentenversicherungsbericht 1995. Bundestags-Drucksache 13/2017.

Eurolink Age (Ed.) (1993): Age discrimination against older workers in the European Community. A comparative analysis. E. Drury. London: Age Concern.

FRERICHS, F. et al. (1996): FRERICHS, F., MICHEL, M., SCEZSNY, C.: Bewältigung des Demographischen Wandels in NRW - Entwicklungen in der Arbeitswelt und Handlungspespektiven für die nachberufliche Lebenswelt. Gemeinsamer Forschungsbericht von Institut für Gerontologie an der Universität Dortmund und Sozialforschungsstelle Dortmund. Dortmund.

GATTER, J., HARTMANN, B.K. (1995): Betriebliche Verrentungspraktiken zwischen arbeitsmarktund rentenpolitischen Interessen. In: Mitteilungen aus der Arbeitsmarkt- und Berufsforschung, 3. S. 412-425.

HOLST, E., SCHUPP, J. (1994): Ist Teilzeit der richtige Weg? Arbeitszeitpräferenzen in West- und Ostdeutschland 1990 bis 1993. DIW-Diskussionspapier, 90. Vervielfältigung. Berlin.

IG Metall-Vorstand (1993): Tarifreform 2000. Ein Gestaltungsrahmen für die Industriearbeit der Zukunft. Frankfurt/M: Eigenverlag.

KARMAUS, W. (1994): Die Bedeutung der Krankheiten des rheumatischen Formenkreises für die Berufs- und Erwerbsunfähigkeitsberentung. In: Behrend, C. (Hrsg.): a.a.O. S. 95-104.

KLAUDER, W. (1992): Ausreichend Mitarbeiter für Tätigkeiten von morgen? In: Bullinger, H.-J. et al. (Hrsg.): Alter und Erwerbsarbeit der Zukunft. Berlin et al.: Springer-Verlag. S. 22-31.

KÖCHLING, A. (1992): Arbeitsplätze der Zukunft. In: forum demographie und politik, 2. S. 60-81.

KOHLI, M. (1994): Altern in soziologischer Perspektive. In: Baltes, P.B. et al. (Hrsg.): Altern und Alter: Ein interdisziplinärer Studientext zur Gerontologie. Berlin: Verlag de Gruyter. S. 231-259.

NAEGELE, G. (1985): Bewältigung des «bergangs in den Ruhestand. In: Dieck, M., Naegele, G., Schmidt, R. (Hg.): «Freigesetzte» Arbeitnehmer im 6. Lebensjahrzehnt - eine neue Ruhestandsgeneration? DZA-Schriftenreihe Beiträge zur Gerontologie und Altenarbeit, 60 . Berlin. S. 33.-50.

NAEGELE, G. (1992): Zwischen Arbeit und Rente. Gesellschaftliche Chancen und Risiken älterer Arbeitnehmer. Augsburg: Maro-Verlag.

NAEGELE, G. (1993): Altersdiskriminierungen in der Erwerbsarbeit. Eine Europäische Vergleichsstudie. Nationaler Report für Deutschland im Auftrag von Eurolink Age. IfGForschungsbericht. Dortmund.

NAEGELE, G. (1994): Demographische und strukturelle Veränderungen in der Arbeitswelt - Neue Herausforderungen an berufliche Fort- und Weiterbildung. In: Veelken, L., Gösken, E., Pfaff, K. (Hrsg.): Gerontologische Bildungsarbeit. neue Ansätze und Modelle. Dortmunder beiträge zur angewandten Gerontologie, 2. Hannover: Vincentz-Verlag. S. 131-150.

Prognos AG (1993): Die Bundesrepublik Deutschland 2000 - 2005 - 2010. Prognos DeutschlandReport Nr. 1. Basel.

RILEY, M.W., RILEY, J.W. jr. (1994): Individuelles und gesellschaftliches Potential des Alterns. In: Baltes P.B. et al. (Hrsg.): a.a.O. S. 437-460. 
ROSENOW, J., NASCHOLD, F. (1993): Ätere Arbeitnehmer - Produktivitätspotential oder personalwirtschaftliche Manövriermasse? Bundesdeutsche Unternehmen im Vergleich zu Schweden und Japan. In Sozialer Fortschritt, 6-7. S. 146-152.

RÜRUP, B., SESSELMEIER, W. (1992): Schrumpfende und alternde deutsche Bevölkerung, Arbeitsmarktpolitische Perspektiven und Optionen. In Klose, H.-J. (Hrsg.): a.a.O. S. 27-50.

RÜRUP, B., SESSELMEIER, W. (1993): Die demographische Entwicklung Deutschlands: Risiken, Chancen, politische Optionen. In Aus Politik und Zeitgeschichte. Beilage zur Wochenzeitung Das Parlament. B 44/93 vom 29.10.1993. S. 3-15.

Der SPIEGEL (12995): Gleitend in die Rente. Ausgabe vom 11.12.1995.

THON, M. (1995): Demografische Aspekte der Arbeitsmarktentwicklung - die Alterung des Erwerbspersonenpotentials. In: Mitteilungen aus der Arbeitsmarkt- und Berufsforschung, 3. S. 290-300.

VOGES, W. (1994): Miffbrauch des Rentensystems? Invalidität las Mittel der Frühverrentung. Frankfurt: Campus-Verlag.

VOGES, W. (1996): Ungleiche Voraussetzungen für Langlebigkeit - Bestimmungsgründe für Mortalität im zeitlichen Verlauf. In: Zeitschrift für Gerontologie und Geriatrie, 1. (In Druck)

WAGNER, A. (1995): Langzeitarbeitslosigkeit: Vielffalt der Formen und differenzierte soziale Lage. In: WSI-Mitteilungen, 12. S. 749-759.

WINKEL et al. (1994): WINKEL, R., ENGELS, D., FRIEDRICH, W., MACHALOWSKI, G.: Betriebliche Umsetzung der gesetzlichen Möglichkeiten eines gleitenden bergangs in den Ruhestand. BMA-Forschungsberichte, 247. Sozialforschung. Bonn.

WOLF, J. (1989): Die Veränderung der Altersgrenzen - Betriebliche Interessen und biographische Perspkektiven. In: Sozialer Fortschritt, 4. S. 92-96. 